Article

\title{
Experimental Study on Coal Gasification in a Full-Scale Two-Stage Entrained-Flow Gasifier
}

\author{
Guangyu Li ${ }^{1}$, Luping Wang ${ }^{1}$, Chaowei Wang ${ }^{2}$, Chang'an Wang ${ }^{2, *}$, Ping $\mathrm{Wu}^{3}$ and Defu Che ${ }^{2}$ \\ 1 State Key Laboratory of High-efficiency Utilization of Coal and Green Chemical Engineering, \\ College of Chemistry and Chemical Engineering, Ningxia University, Yinchuan 750021, China; \\ liguangyu@nxu.edu.cn (G.L.); luping_wang1996@163.com (L.W.) \\ 2 State Key Laboratory of Multiphase Flow in Power Engineering, School of Energy and Power Engineering, \\ Xi'an Jiaotong University, Xi'an 710049, China; wangchaowei@stu.xjtu.edu.cn (C.W.); \\ dfche@mail.xjtu.edu.cn (D.C.) \\ 3 China Huaneng Tianjin IGCC CO., LTD, 2218 Huaihe Avenue, Lingang Economic Districit, \\ Tianjin 300452, China; pi.wu.greengen@163.com \\ * Correspondence: changanwang@mail.xjtu.edu.cn; Tel.: +86-029-82665185
}

Received: 29 August 2020; Accepted: 18 September 2020; Published: 21 September 2020

check for updates

\begin{abstract}
In this paper, coal gasification characteristics in the reductor were investigated in a full-scale two-stage pressurized entrained-flow gasifier, which has been seldom conducted previously. The present study aimed at elucidating the effects of gasifying agent concentration, coal input rate, and operation period under full reductor load on the performance of a utility two-stage pressurized entrained-flow gasifier for the first time. When the steam input in the combustor was raised from $3318 \mathrm{~kg} / \mathrm{h}$ to $5722 \mathrm{~kg} / \mathrm{h}$, the total outputs of $\mathrm{H}_{2}, \mathrm{CO}$, and $\mathrm{CO}_{2}$ were increased by $1765 \mathrm{Nm}^{3} / \mathrm{h}$ and $2063 \mathrm{Nm}^{3} / \mathrm{h}$, respectively, while the $\mathrm{CH}_{4}$ output was decreased by $49 \mathrm{Nm}^{3} / \mathrm{h}$. The coal conversion rate was minimal at low steam input. In addition, more coal gasified in the reductor could increase the output of $\mathrm{CH}_{4}$, while $\mathrm{CH}_{4}$ could reach $1.24 \%$ with the coal input in the range of $8000-10,000 \mathrm{~kg} / \mathrm{h}$. The present work can offer a further understanding of the gasification performance in the reductor of the full-scale two-stage pressurized entrained-flow gasifier, and motivates the potential for clean utilization of coal resource.
\end{abstract}

Keywords: HNCERI; two-stage entrained-flow gasifier; gasifying agent; carbon conversion; clean coal technology

\section{Introduction}

To ensure the sustainable and effective use of coal, an abundant fossil fuel, the environmental pollution issues associated with coal consumption are required to be adequately addressed [1-4], especially in China. Coal gasification technology which converts coal into electricity, hydrogen, chemical products, and other valuable energy is versatile and clean [5-7]. The deployment of $\mathrm{CO}_{2}$ capture technology is more feasible in coal gasification systems due to coal decarbonization, producing clean syngas. The clean syngas can be used for power generation and production of chemicals and hydrogen [5-7]. Thus, coal gasification is an important sustainable clean coal technology.

Coal gasification technology is a multiphase reaction technology involving both gaseous phase and solid phase reactions [8-11]. This implies complex interaction of pyrolysis, heterogeneous reactions of carbon with $\mathrm{O}_{2}, \mathrm{CO}_{2}$, and $\mathrm{H}_{2} \mathrm{O}$, and homogeneous reactions [12]. The entrained-flow approach has received significant attention in comparison to the fixed-bed and fluidized-bed for coal gasification due to its improved multiphase reaction rates, which is more promising for large-scale application. Compared with the fixed-bed and fluidized-bed technologies, the entrained-flow gasification technology 
accomplishes gasification in several seconds with a high conversion rate of coal. The entrained-flow gasification technology accomplishes a high gasification rate of coal through the following means $[9,13]$ : (1) the raw coal is pulverized to increase contact surface area for multiphase reactions; (2) the pure oxygen is used as gasifying agent to promote the reaction rate; (3) the gasification temperature is further increased.

As an endothermic reaction, the reaction rate of coal gasification increases with temperature. However, high temperature is expected to bring about an increase in oxygen consumption, which in turn means lower yield of syngas in the gasification process. This implies higher cost, due to the need for larger down-stream dehumidifier. However, the gasification temperature of most entrained-flow gasification technologies is approximately $1500{ }^{\circ} \mathrm{C}$, because they use slag-tapping technique which requires that gasification temperature be at least $100{ }^{\circ} \mathrm{C}$ higher than ash melting temperature. The two-stage entrained-flow gasification technology was developed to address the need for high temperature zone needed for slag-tapping technique, and to create optimum temperature zone for effective gasification reaction. The temperature for reaction area of the first stage is approximately $1500{ }^{\circ} \mathrm{C}$, which meets the need for slag-withdrawal, and the temperature for the reaction area of the second stage declines to $1100-1200^{\circ} \mathrm{C}$, a temperature that is the most efficient for gasification reactions. Therefore, the gasification efficiency is improved, and the specific oxygen consumption is lowered. In the reaction region of the second stage, the pulverized coal is injected without oxygen injection at the same time. The Huaneng Clean Energy Research Institute (HNCERI) of China has also developed a two-stage entrained-flow gasification technology, which has a very high conversion rate of carbon [9].

Many studies have been reported in literature on two-stage coal gasification. Albal et al. [8] focused the influential factors on an advanced two-stage gasification system, using an experimental approach. Chen et al. [14-17] extensively studied the gasification reactions and reactant mixing process with a simulation method. Watanabe and Otaka [18] simulated a $2 \mathrm{t} /$ day gasifier using CFX software. Shi et al. [19] performed a simulation of a water-coal-slurry gasifier. Wang et al. [20] also simulated the coal gasification process. Liu et al. [21] and Yang et al. [22] simulated the gasification behaviors of coal in a similar way. Peralta and Wang et al. $[23,24]$ investigated the gasification characteristics of various Chinese coals under conditions related to the entrained-flow gasification process. As for the HNCERI gasification process, Li et al. [25] experimentally studied the contact between slag viscosity and temperature. Ren and co-workers [13] evaluated the application of a two-stage pressurized dry pulverized-coal gasifier in the Tianjin demonstration power plant of integrated gasification combined cycle (IGCC) and compared the performance of the first stage and the second stage gasification. In addition, a novel two-stage entrained-bed gasification system has been proposed by Gao et al. [26], and they simulated the coal pyrolysis and gasification characteristics using Aspen Plus software as well. Watanabe et al. [27] assessed the influences of $\mathrm{CO}_{2}$ recirculation on gasification performance of a two-stage coal gasifier in an oxy-fuel IGCC plant using a numerical method. Wang et al. [28] numerically studied the coal gasification performance in a two-stage entrained flow gasifier using computational fluid dynamics (CFD) software. The soot formation during coal gasification in two-stage entrained-flow gasifiers was rarely specifically paid attention to [29]. During the past few years, extensive investigations on biomass gasification via the two-stage gasification process have been conducted, owing to the increasing attention on biomass energy. For example, Jeong et al. [30] studied the two-stage gasification of biomass via active carbon, for the sake of enhancing the hydrogen production and lowering tar production using lab-scale and pilot-scale experimental systems. They also evaluated the co-gasification performance of coal and dried sewage sludge [10]. Jahromi et al. [31] developed a CFD model for biomass gasification and syngas formation. Niu et al. [32] proposed a new two-stage gasifier to gasify biomass, which consists of a swirl-melting furnace and a fluidized bed gasifier. A new concept of two-stage gasification for biomass was proposed by Pei et al. [33] to overcome the disadvantages of biomass gasification. A $1.5 \mathrm{MW}_{\text {th }}$ demonstration plant was also designed, and operated, to evaluate the technical and economic feasibility. The gasification behaviors of coal differ greatly from those of biomass, due to their considerably different inherent properties. 
However, further experiments on coal gasification characteristics in the second stage (also known as reductor) are still needed. Most previous investigations have been conducted only under lab-scale and pilot-scale conditions. There are few reported experimental investigations to clarify the key operation parameters that affect coal gasification and reaction between the gasification products. Moreover, there are insufficient experiments to test coal gasification characteristics in the reductor under high load and long period of the operation's condition. Therefore, the gasification features of the reductor are still unclear.

In the present work, the effects of different concentrations of gasifying agents and coal input rates on coal gasification characteristics in the reductor were experimentally investigated in a full-scale plant, and the gasifier was also tested for a long period under high load condition of the second stage. The effects of steam input to the gasifier and the amount of coal fed into the reductor on syngas production $\left(\mathrm{CO}_{2}, \mathrm{H}_{2}, \mathrm{CO}\right.$, and $\left.\mathrm{CH}_{4}\right)$ were studied as well. In addition, the effect of steam addition on the reaction between the gasification products was further analyzed, based on the element balance. This is the first publication of the performance of the reductor under a range of conditions. The test results were compared with existing data to determine the two-stage reaction characteristics. The present study will not only elucidate coal gasification characteristics in the reductor, but also provide the basis for the design and operation of a two-stage entrain-flow gasifier.

\section{Experimental}

\subsection{Coal Sample}

The bituminous coal used in the present study was Shenhua bituminous coal. The proximate and ultimate analyses of Shenhua coal on the as-received basis (abbreviated as "ar") are shown in Table 1. The particle size distribution of the coal sample can be seen in Table 2. The carbon dioxide reactivity, with the experimental coal particle as a function of temperature, is illustrated in Figure 1, and the reactivity was measured according to Chinese GB Standard [GB/T 220-2001].

Table 1. Proximate and ultimate analyses of coal sample (wt $\%$, as-received basis (ar)).

\begin{tabular}{cc}
\hline Net Calorific Value $\left(\mathbf{M J} \cdot \mathbf{k g}^{\mathbf{- 1}}\right)$ & $\mathbf{2 4 . 3 6}$ \\
\hline Proximate analysis (wt\% as received basis) & \\
Volatile matter & 28.33 \\
Fixed carbon & 50.20 \\
Ash & 8.87 \\
Moisture & 12.60 \\
\hline Ultimate analysis (wt\% as received basis) & \\
Carbon & 63.25 \\
Hydrogen & 3.45 \\
Oxygen & 10.65 \\
Nitrogen & 0.79 \\
Sulphur & 0.38 \\
\hline
\end{tabular}

Table 2. Particle size distribution of test coal.

\begin{tabular}{lcccccccccc}
\hline $\begin{array}{c}\text { Mass fraction } \\
{[\mathrm{wt} \%]}\end{array}$ & 1.6 & 9.8 & 12.4 & 34.2 & 8.8 & 11.3 & 5.8 & 4.7 & 3.5 & 7.9 \\
\hline $\begin{array}{c}\text { Min. Max. } \\
\text { diameters } \\
{[\mu \mathrm{m}]}\end{array}$ & $0 \sim 1$ & $1 \sim 5$ & $5 \sim 10$ & $10 \sim 35$ & $35 \sim 45$ & $45 \sim 60$ & $60 \sim 70$ & $70 \sim 80$ & $80 \sim 90$ & $>90$ \\
\hline
\end{tabular}




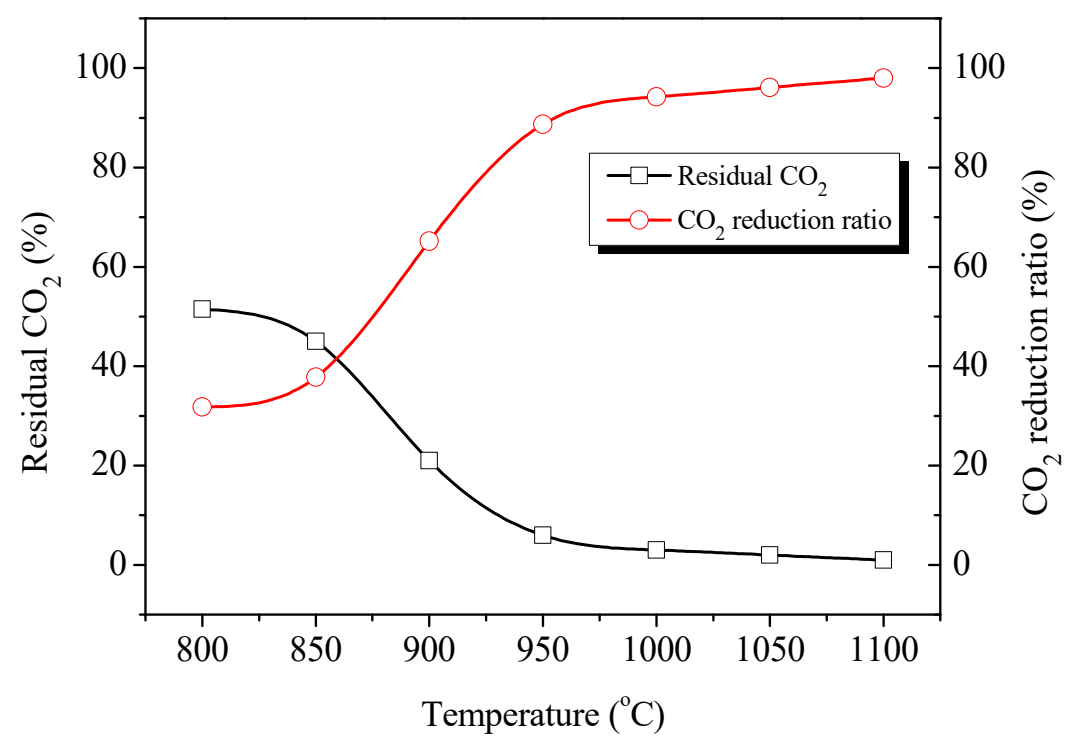

Figure 1. The carbon dioxide reactivity of experimental coal.

\subsection{Description of the Full-Scale Facility}

A schematic diagram of the HNCERI plant is shown in Figure 2. Coal milled and dried in the "coal milling and drying" unit is fed into the coal burner of the gasifier via the "coal pressurization and feeding" (lock hopper) system. The coal reacts in the two-stage gasifier with the blast (steam diluted oxygen) to form syngas and slag. The syngas which leaves the top of the gasifier is approximately $800{ }^{\circ} \mathrm{C}$, and is then further cooled in the syngas cooler (SGC) to $300^{\circ} \mathrm{C}$. The slag mostly leaves the gasifier as molten slag and is quenched. A forced water circulation is maintained over the membrane wall to absorb heat and produce medium pressure steam. The fly ash carried with the syngas is removed in the "dry solids removal" section and is discharged into storage. The slag is then drained of its water, and is transported to off-site. The fly ash is sent to the storage and disposal facilities after stripping and cooling. The virtually dust-free syngas is scrubbed in the "wet scrubbing" section. The heat which is absorbed in the slag bath is removed via a slag bath-water circulation loop.

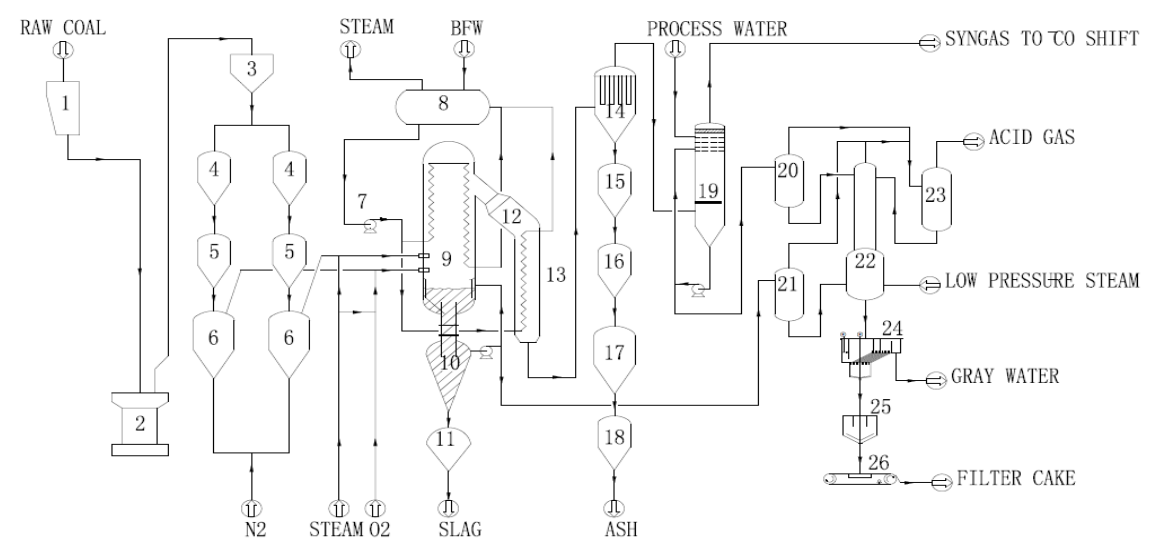

Figure 2. Schematic diagram of the entrained-flow gasification of the Huaneng Clean Energy Research Institute (HNCERI) process: 1. Raw coal bunker; 2. Coal mill; 3. Pulverized coal bag house; 4. Pulverized coal storage; 5. Pulverized coal sluice vessel; 6. Coal feed vessel; 7. Middle-pressure (MP) circulation pump; 8. MP steam drum; 9. Gasifier; 10. Slag accumulator; 11. Slag sluice vessel; 12. Syngas duct; 13. Syngas cooler; 14 . High-pressure high-temperature (HPHT) filter; 15 . Fly ash sluice vessel; 16. Fly ash stripper/cooling vessel; 17 . Fly ash storage vessel; 18 . Fly ash blow-egg; 19. Scrubber; 20. Scrubber bleed vessel; 21. Slurry bleed vessel; 22. Slurry stripper; 23. Reflux vessel; 24. Clarifier; 25. Slurry settler; 26 . Vacuum belt filter. 
Dimensions of the experimental facility can be referred to our previous publication [13]. The facility consists of a combustor and a reductor. The gasifier is comprised of two levels of injectors. The combustor contains four burners, and the reductor contains two injectors. The pulverized coal, oxygen, and steam enter the combustor through different injectors. The pulverized coal and char are burnt in fuel-rich condition $\left(99.6 \% \mathrm{O}_{2} / 0.4 \% \mathrm{~N}_{2}\right)$ in the combustor. The liquid slag is separated from syngas. The combustion and gasification reactions take place simultaneously in the combustor, and the steam is an agent of gasification. The pulverized coal and steam enter the reductor through different injectors. In the reductor, the gasification reaction is the only reaction to generate the syngas. The temperature of syngas is cooled by heat absorption due to the gasification process.

\subsection{Description of the Full-Scale Facility}

The present experiments were divided into three parts. In part I, the flow rate of steam in the combustor was progressively increased to improve the concentrations of gasifying agents in the reductor, and their effects were examined. In part II, the flow rate of coal in the reductor was progressively increased to study how coal flow rate affects the gasification reaction. In Part III, under high load condition, the normal operating data were recorded to test the performance of the second stage, which could be compared with the results from Part I and Part II. Table 3 shows the typical experimental conditions in the present study. Moreover, Table 4 exhibits the information of the measuring instruments.

Table 3. The experimental conditions in the present study.

\begin{tabular}{ccccccccc}
\hline & & & \multicolumn{2}{c}{ Part I } & \multicolumn{2}{c}{ Part II } & \multicolumn{2}{c}{ Part III } \\
\hline & & & I-1 & I-2 & II-1 & II-2 & III-1 & III-2 \\
\hline Reactor pressure & $P$ & $\mathrm{MPa}$ & 3.0 & 3.0 & 3.0 & 3.0 & 3.0 & 3.0 \\
Combustor coal rate & $\mathrm{G}_{\mathrm{C}, \mathrm{coal}}$ & $\mathrm{kg} / \mathrm{h}$ & 63,265 & 62,124 & 61,520 & 62,042 & 71,802 & 69,729 \\
Combustor oxygen rate & $\mathrm{G}_{\mathrm{C}, \mathrm{O} 2}$ & $\mathrm{~kg} / \mathrm{h}$ & 56,724 & 56,709 & 57,300 & 57,318 & 61,963 & 60,444 \\
Combustor steam rate & $\mathrm{G}_{\mathrm{C}, \mathrm{H} 2 \mathrm{O}}$ & $\mathrm{kg} / \mathrm{h}$ & 3200 & 5849 & 5362 & 6497 & 4388 & 5586 \\
Reductor coal rate & $\mathrm{G}_{\mathrm{R}, \mathrm{coal}}$ & $\mathrm{kg} / \mathrm{h}$ & 4755 & 5018 & 5481 & 6639 & 8198 & 10,087 \\
Reductor steam rate & $\mathrm{G}_{\mathrm{R}, \mathrm{H} 2 \mathrm{O}}$ & $\mathrm{kg} / \mathrm{h}$ & 1760 & 1601 & 1600 & 1600 & 4867 & 4667 \\
Combustor $\mathrm{O}_{2} /$ coal ratio & & $\mathrm{kg} / \mathrm{kg}$ & 0.897 & 0.913 & 0.931 & 0.924 & 0.863 & 0.867 \\
Combustor $\mathrm{H}_{2} \mathrm{O} /$ coal ratio & & $\mathrm{kg} / \mathrm{kg}$ & 0.051 & 0.094 & 0.087 & 0.105 & 0.061 & 0.080 \\
Reductor $\mathrm{H}_{2} \mathrm{O} /$ coal ratio & & $\mathrm{kg} / \mathrm{kg}$ & - & - & 0.365 & 0.301 & 0.594 & 0.463 \\
Total $\mathrm{O}_{2} /$ coal ratio & & $\mathrm{kg} / \mathrm{kg}$ & 0.846 & 0.857 & 0.869 & 0.851 & 0.775 & 0.757 \\
Total $\mathrm{H}_{2} \mathrm{O} /$ coal ratio & & $\mathrm{kg} / \mathrm{kg}$ & 0.074 & 0.113 & 0.106 & 0.12 & 0.116 & 0.128 \\
\hline
\end{tabular}

Table 4. The information of measuring instruments.

\begin{tabular}{ccc}
\hline Parameter & Type of Measuring Instrument & Manufacturer \\
\hline Pulverized coal flow rate & Nuclear radiation measurement & Bertohod \\
Oxygen flow rate & Vortex flowmeter & Luosimengte \\
Steam flow rate & Vortex flowmeter & Luosimengte \\
Syngas flow rate & Orifice flowmeter & Luosimengte \\
Syngas component & Gas chromatography analyzer & ABB \\
\hline
\end{tabular}

The gasification study during Part I was conducted using the following procedure. The initial flow rate of steam in each burner was $800 \mathrm{~kg} / \mathrm{h}$ in the combustor. During the experiments, the flow rate of steam was increased by $50 \mathrm{~kg} / \mathrm{h}$ each time, and was kept stable for 5-10 min until it reached the preset value. The same operation was repeated until the flow rate of steam reached $1500 \mathrm{~kg} / \mathrm{h}$. During these experiments, other operating parameters affecting the gasification process in the reductor were kept constant. The main parameters in the combustor were the flow rate of coal and gasification temperature, while the corresponding ones were the flow rates of coal and steam in the reductor. For the combustor, 
the stabilization of gasification temperature was controlled by adjusting the oxygen-coal ratio, which is defined as follows:

$$
\mathrm{O}_{2} / \text { coal }=G_{\text {oxygen }} / G_{\text {coal }}
$$

For Part II, the initial flow rate of coal was $3600 \mathrm{~kg} / \mathrm{h}$. The flow rate was increased by $500 \mathrm{~kg} / \mathrm{h}$ each time, and kept constant for $2 \mathrm{~h}$. This procedure for increasing coal flow rate was repeated until the coal flow rate reached $6000 \mathrm{~kg} / \mathrm{h}$, and then the flow rate was kept for $12 \mathrm{~h}$. During these experiments, other operating parameters which could affect the gasification process in the reductor were kept unchanged. The main parameters were the flow rates of coal, oxygen, and steam, the gasification temperature in the combustor, and the flow rate of steam in the reductor.

In Part III, the gasification equipment operated for a long period, and under full-load condition. The experimental conditions were adjusted according to the downstream load, and the typical operating data were recorded on various dates for a very long duration time.

\subsection{Sampling and Gas Analysis Methods}

The amounts of pulverized coal, oxygen, water steam, syngas flow, components, and coal ash flow were all measured with on-line instruments. Each burner of the gasifier has a pulverized coal feed line with a flow meter. The flow rate of coal obtained from the flow meter was compared with the value obtained by weighing pulverized coal storage. Each oxygen and steam line have a flow meter attached. The combined flow of oxygen and steam with a flowmeter provided a means of comparing the separate measurements from oxygen and steam lines.

The exit syngas was measured with an on-line coal gas flow meter after wet-cleaning, and coal ash was collected in a storage tank in the ash removing system. The final products of hot syngas were cooled down after the removal of particulates and acid gases.

The dry gas flow rate was calculated as:

$$
V_{\text {dry,gas }}=V_{\text {wet,gas }} \times\left(1-P_{\text {sat }} / P_{\text {wet }}\right),
$$

where $P_{\text {sat }}(\mathrm{MPa})$ is the saturation pressure, $P_{\text {wet }}(\mathrm{MPa})$ is the pressure of wet gas, $V_{\text {wet,gas }}\left(\mathrm{Nm}^{3} / \mathrm{h}\right)$ is the flow rate of wet gas, and $V_{\text {dry,gas }}\left(\mathrm{Nm}^{3} / \mathrm{h}\right)$ is the flow rate of dry product gas.

The ash flow rate, $G_{\text {ash }}(\mathrm{kg} / \mathrm{h})$ was calculated as follows:

$$
G_{\mathrm{ash}}=\Delta m_{\mathrm{ash}} / \Delta t_{\mathrm{ash}}
$$

where $\Delta t_{\text {ash }}(\mathrm{h})$ is the ash sampling interval, and $\Delta m_{\mathrm{ash}}(\mathrm{kg})$ is the increasing mass of ash.

\section{Results and Discussion}

\subsection{Effects of Gasifying Agents}

The effects of gasifying agents on gasification products are depicted in Figure $3 a-d$ and Table 5. Figure $3 a-d$ shows an increase in the production of syngas as the flow rate of steam input into the combustor is increased. The $\mathrm{CH}_{4}$ yield falls with a rise of the flow rate of steam. Table 4 shows that the volume fraction increment of $\mathrm{CO}_{2}$ is greater than those of $\mathrm{H}_{2}$ and $\mathrm{CO}$, but the flow rate increment of $\mathrm{CO}_{2}$ is lower than those of $\mathrm{H}_{2}$ and $\mathrm{CO}$, owing to the density difference of $\mathrm{CO}_{2}$ and other various gases. 

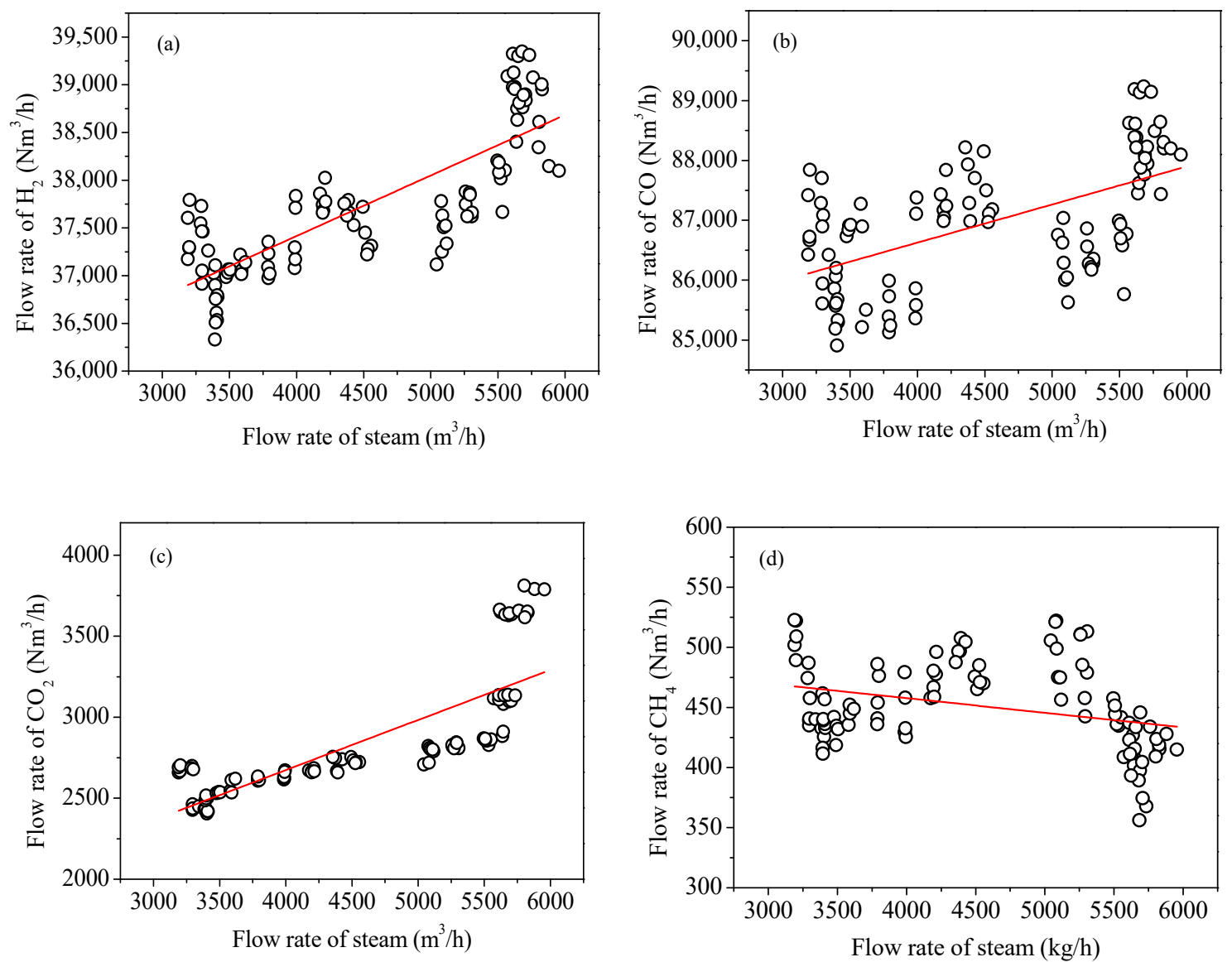

Figure 3. Variations of syngas production with steam flow rate: (a) $\mathrm{H}_{2} ;(\mathbf{b}) \mathrm{CO}$; (c) $\mathrm{CO}_{2} ;$ (d) $\mathrm{CH}_{4}$.

Table 5. The change of syngas production with change of steam flow rate in the combustor.

\begin{tabular}{|c|c|c|c|c|c|}
\hline \multirow{2}{*}{ Material Flow } & \multirow{2}{*}{ Steam Input } & \multicolumn{4}{|c|}{ Syngas Production } \\
\hline & & $\mathbf{H}_{2}$ & $\mathrm{CO}$ & $\mathrm{CO}_{2}$ & $\mathrm{CH}_{4}$ \\
\hline Units & $\mathrm{kg} / \mathrm{h}$ & $\mathrm{Nm}^{3} / \mathrm{h}$ & $\mathrm{Nm}^{3} / \mathrm{h}$ & $\mathrm{Nm}^{3} / \mathrm{h}$ & $\mathrm{Nm}^{3} / \mathrm{h}$ \\
\hline Part I-1 & 3318 & 37,104 & 86,264 & 2536 & 459 \\
\hline Part I-2 & 5722 & 38,869 & 88,327 & 3464 & 409 \\
\hline Increment & 2403 & 1765 & 2063 & 928 & -49 \\
\hline
\end{tabular}

The increase in the syngas output, caused by increasing the steam input, shows that extra carbon was converted. The reactions which involved steam in the gasification process are described below:

$$
\begin{gathered}
\mathrm{C}+\mathrm{H}_{2} \mathrm{O} \rightarrow \mathrm{CO}+\mathrm{H}_{2}, \\
\mathrm{C}+2 \mathrm{H}_{2} \mathrm{O} \rightarrow \mathrm{CO}_{2}+2 \mathrm{H}_{2}, \\
\mathrm{CO}+\mathrm{H}_{2} \mathrm{O} \rightarrow \mathrm{CO}_{2}+\mathrm{H}_{2},
\end{gathered}
$$

More $\mathrm{CO}_{2}$ was generated from reactions (5) and (6); thus, it promoted reaction (7).

$$
\mathrm{C}+\mathrm{CO}_{2} \rightarrow 2 \mathrm{CO}
$$

The increase in steam concentration suppressed reaction (8), from which methane was produced.

$$
\mathrm{CO}+3 \mathrm{H}_{2} \rightarrow \mathrm{CH}_{4}+\mathrm{H}_{2} \mathrm{O}
$$


Based on chemical reactions (4)-(8), the hydrogen atoms originate from steam-involved reactions and $\mathrm{CH}_{4}$ decomposition. The reactions (7) and (8) could occur at high temperature. The gasification temperature of this device is above $1150{ }^{\circ} \mathrm{C}$, therefore the reactions could occur. From elemental balance, the flow rate of $\mathrm{H}_{2}$ was increased by $1765 \mathrm{Nm}^{3} / \mathrm{h}$, in which $98 \mathrm{Nm}^{3} / \mathrm{h}$ of the increment was contributed by $\mathrm{CH}_{4}$ decomposition, and $1667 \mathrm{Nm}^{3} / \mathrm{h}$ was from steam-involved reactions. It shows that $56 \%$ steam involved in the reaction, and $893 \mathrm{~kg} / \mathrm{h}$ carbon can be gasified according to reaction (4), and the carbon conversion rate in the reductor was increased by $33 \%$. The quality of carbon gasified by the increased steam in reductor can also be calculated by mass balance. During the experiments, the amount of input is mainly steam and oxygen and the output species are principally $\mathrm{H}_{2}, \mathrm{CO}, \mathrm{CO}_{2}$, and $\mathrm{CH}_{4}$. The difference between the output species and the input is the residual carbon which participates in the reactions (4) and (8). The increase in steam is $2403 \mathrm{~kg} / \mathrm{h}$, the increase in oxygen is $205 \mathrm{~kg} / \mathrm{h}$, and the increase in syngas is $4524 \mathrm{~kg} / \mathrm{h}$. Therefore, the residual carbon involved in the reaction is $1916 \mathrm{~kg} / \mathrm{h}$, and the carbon conversion rate in reductor was increased by $71 \%$. Consequently, adding steam increased the conversion rate of carbon in reductor, which also be reflected in the downstream power generation load.

The flow increments of steam and $\mathrm{O}_{2}$ in the combustor resulted in the increment of oxygen atoms of $\mathrm{CO}$ and $\mathrm{CO}_{2}$. When the steam flow rate in the combustor was increased, the $\mathrm{O}_{2}$ flow rate was also increased to keep the gasification temperature relatively stable. The decrease observed with $\mathrm{CH}_{4}$ flow rate was caused by the increase in steam concentration, which promoted the occurrence of the reverse reaction (8).

\subsection{High Load Reaction Characteristics in the Reductor}

The productions of $\mathrm{H}_{2}, \mathrm{CO}, \mathrm{CO}_{2}$, and $\mathrm{CH}_{4}$ increased with the coal feeding rate in the reductor and the contents of $\mathrm{H}_{2}$ and $\mathrm{CO}$ were also increased (see Figure $4 \mathrm{a}-\mathrm{d}$ and Table 6). Increasing the concentrations of the gasifying agents can enhance the contact or interaction for coal and gasifying agents. As expected, the increased contact promoted the gasification reaction, as shown in Figure 4a-d. In the inlet of the reductor, the syngas temperature is $1500^{\circ} \mathrm{C}$, and the syngas temperature dropped to $1150{ }^{\circ} \mathrm{C}$ at the outlet of the reductor. The conditions in the furnace are complex, therefore the temperature could not be measured accurately, and the temperature of reductor is around $1150{ }^{\circ} \mathrm{C}$. From Table 6, it can be found that the volume fraction increment of $\mathrm{CH}_{4}$ is higher than those of other species.
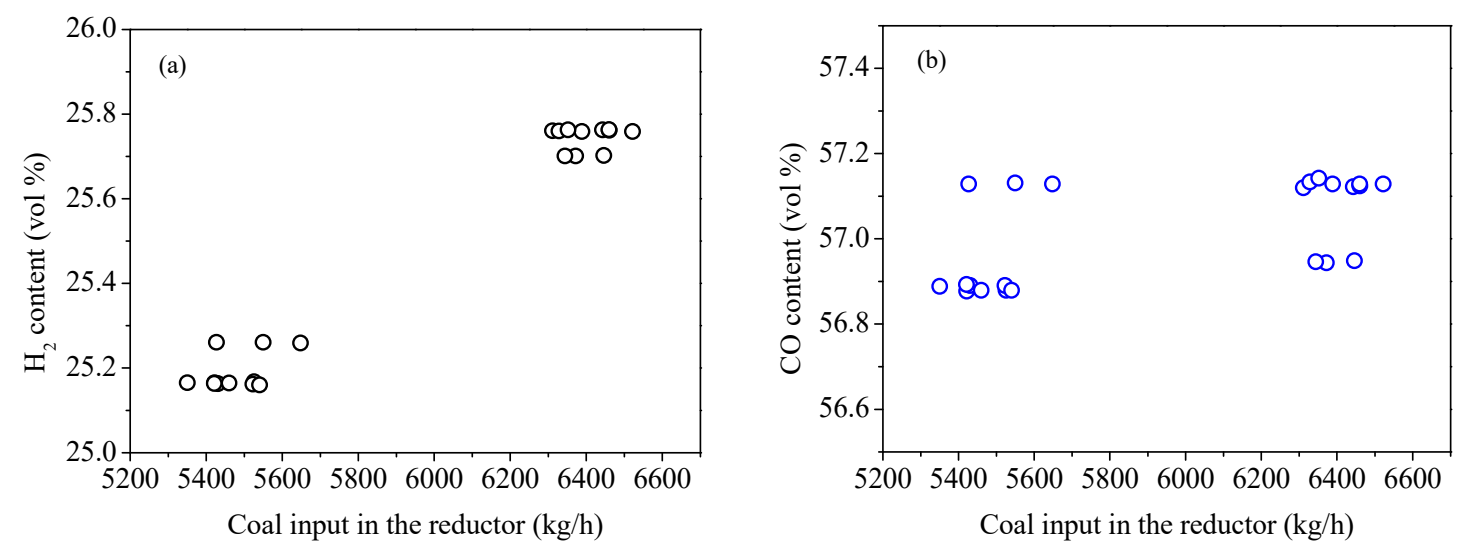

Figure 4. Cont. 

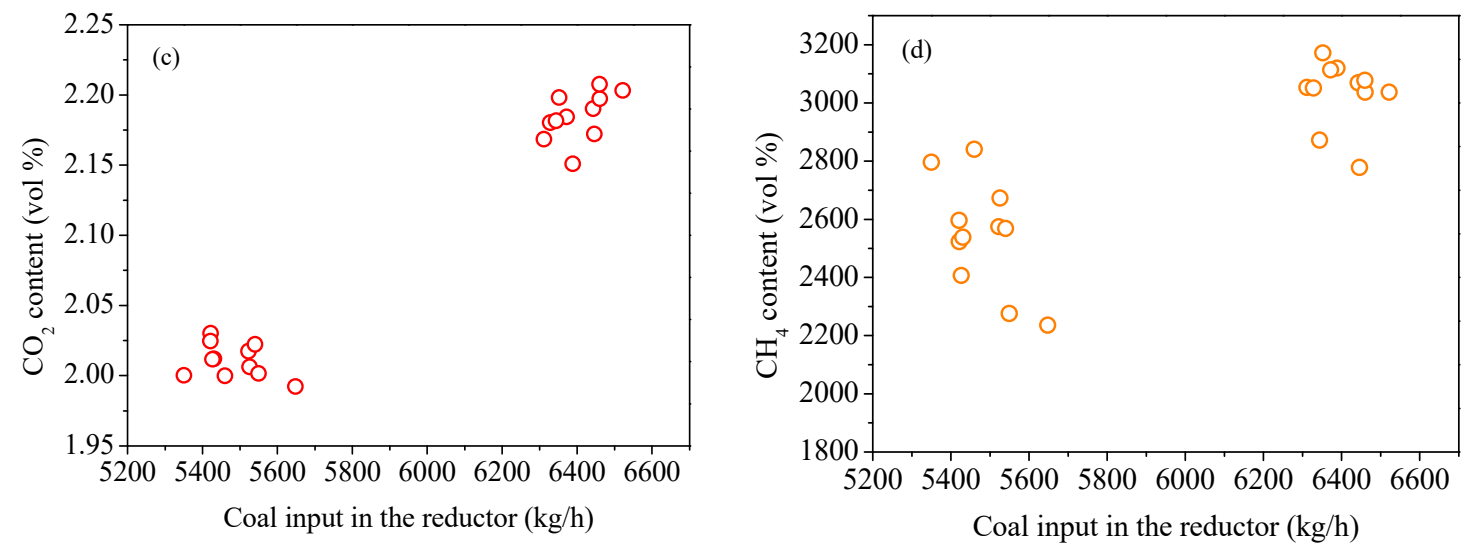

Figure 4. Variation of $\mathrm{H}_{2}, \mathrm{CO}, \mathrm{CO}_{2}$, and $\mathrm{CH}_{4}$ with coal input in the reductor: (a) $\mathrm{H}_{2} ;$ (b) $\mathrm{CO}$; (c) $\mathrm{CO}_{2}$; (d) $\mathrm{CH}_{4}$.

Table 6. The change of syngas production with coal feeding rate in the reductor.

\begin{tabular}{|c|c|c|c|c|c|c|}
\hline \multirow{2}{*}{$\begin{array}{c}\text { Material } \\
\text { Flow }\end{array}$} & \multirow{2}{*}{$\begin{array}{c}\text { Coal } \\
\text { Feeding }\end{array}$} & \multirow{2}{*}{$\begin{array}{c}\text { Steam } \\
\text { Increased }\end{array}$} & \multicolumn{4}{|c|}{ Syngas Production } \\
\hline & & & $\mathrm{H}_{2}$ & $\mathrm{CO}$ & $\mathrm{CO}_{2}$ & $\mathrm{CH}_{4}$ \\
\hline Units & $\mathrm{kg} / \mathrm{h}$ & $\mathrm{kg} / \mathrm{h}$ & $\mathrm{Nm}^{3} / \mathrm{h}$ & $\mathrm{Nm}^{3} / \mathrm{h}$ & $\mathrm{Nm}^{3} / \mathrm{h}$ & $\mathrm{Nm}^{3} / \mathrm{h}$ \\
\hline Part II-1 & 5481 & 6962 & 37,136 & 83,958 & 3977 & 376 \\
\hline Part II-2 & 6639 & 8124 & 38,447 & 85,241 & 4366 & 453 \\
\hline Increment & 1158 & 1162 & 1311 & 1283 & 389 & 77 \\
\hline
\end{tabular}

The increase in coal and steam feeding rates in the reductor leads to more syngas generation. The result of material balance calculation is shown as follows:

$$
\begin{gathered}
m_{\mathrm{t}}=m_{\mathrm{c}}+m_{\mathrm{s}}=2320 \mathrm{~kg} / \mathrm{h}, \\
m_{\mathrm{g}}=m_{\mathrm{H} 2}+m_{\mathrm{CO}}+m_{\mathrm{CO} 2}+m_{\mathrm{CH} 4}=2540 \mathrm{~kg} / \mathrm{h},
\end{gathered}
$$

where $m_{\mathrm{t}}, m_{\mathrm{c}}, m_{\mathrm{s}}, m_{\mathrm{g}}, m_{\mathrm{H}_{2}}, m_{\mathrm{CO}}, m_{\mathrm{CO}_{2}}$ and $m_{\mathrm{CH}_{4}}$ represent the flow rate increment of total material, coal, steam, syngas, $\mathrm{H}_{2}, \mathrm{CO}, \mathrm{CO}_{2}$, and $\mathrm{CH}_{4}$, respectively.

The flow rate increase in the component input is close to that of the syngas output, which means most coal was gasified during coal pyrolysis and the gasification process. $\mathrm{H}_{2}$ and $\mathrm{CO}$ were the main products. In addition, the flow rate of $\mathrm{CO}_{2}$ was increased, because the increase in steam to the gasifier promoted the water-gas shift reaction (6). This also implied that lower temperature led to $\mathrm{more}_{4} \mathrm{CH}_{4}$ being generated during the coal pyrolysis and the gasification process.

\subsection{Carbon Conversion Rate}

The carbon conversion efficiency (CCE) in the reductor with ash balance obtains coal input and the char samples. The CCE (\%) can be calculated using the ash balance method:

$$
\mathrm{CCE}_{\mathrm{ash}}=\left[1-\left(G_{\mathrm{ash}} \times C_{\mathrm{ash}} \%\right) /\left(G_{\mathrm{R}, \mathrm{coal}} / C_{\mathrm{coal}} \%\right)\right] \times 100
$$

where $C_{\text {ash }}(w t \%)$ is the carbon content in the ash, and $C_{\text {coal }}(w t \%)$ is the content of carbon of feed coal. The carbon in the slag and dissolved in the water was not considered.

As shown in Table 7, the carbon conversion efficiency in the reductor was between $70 \%$ and $80 \%$. Since moisture and volatile matter are in the gaseous phase, it can be concluded that $80-90 \%$ of the weight of coal was gasified. Shenhua coal has a superior gasification reactivity, as shown in Figure 1, while the reduction rate of $\mathrm{CO}_{2}$ was $98 \%$ and the residual $\mathrm{CO}_{2}$ volume fraction was only $1 \%$ when the test temperature was $1100{ }^{\circ} \mathrm{C}$. However, the carbon conversion rate in Table 7 was 
$70-80 \%$ when the gasifying temperature in the reductor was beyond $1100{ }^{\circ} \mathrm{C}$. The carbon conversion performance disagreed with carbon dioxide reactivity of the coal measured in Figure 1. Different results between the industrial gasifier and those measured in the laboratories were caused by different reaction conditions. In addition, the experimental results were measured according to the Chinese GB Standard [GB/T 220-2001]. The reaction time was shorter in the industrial gasifier, and the contact time of coal and gasifying agents was also shorter than that measured in the laboratories.

Table 7. The carbon conversion rate of coal input in the reductor.

\begin{tabular}{lcccccccc}
\hline Parameters & Units & II-1 & II-2 & II-3 & II-4 & II-5 & II-6 & II-7 \\
\hline Carbon content of A class ash & $\%$ & 9.25 & 11.51 & 12.13 & 13.66 & 16.12 & 13.17 & 19.14 \\
Carbon content of B class ash & $\%$ & 11.13 & 21.74 & 23.65 & 28.87 & 29.04 & 18.17 & 29.21 \\
A class Ash quantity & $\mathrm{t} / \mathrm{h}$ & 2 & 2.21 & 1.82 & 2.1 & 2.15 & 2.21 & 2.31 \\
B class Ash quantity & $\mathrm{t} / \mathrm{h}$ & 1.86 & 2.05 & 1.56 & 2.01 & 1.89 & 1.93 & 2.01 \\
Coal input in combustor & $\mathrm{t} / \mathrm{h}$ & 56.4 & 62.2 & 63.2 & 62.3 & 61.5 & 61.6 & 62.1 \\
Coal input in reductor & $\mathrm{t} / \mathrm{h}$ & 3.25 & 4.63 & 4.63 & 5.13 & 6.13 & 5.75 & 7.5 \\
Coal fixed carbon & $\%$ & 51.17 & 51.17 & 51.17 & 52.06 & 51.43 & 51.43 & 50.97 \\
Ash content of coal & $\%$ & 13.16 & 13.16 & 13.16 & 12.14 & 12.74 & 12.74 & 12.21 \\
Carbon conversion rate & $\%$ & 76.8 & 70.4 & 75.2 & 68 & 72 & 78.4 & 72.8 \\
\hline
\end{tabular}

\subsection{Long Period Test}

Table 8 shows the impact of operation time on the gasification characteristics. The highest coal feed rate was $10,087 \mathrm{~kg} / \mathrm{h}$. During this operation, the water-coal ratio in the stage I reaction was lower than that of part I in Table 3, and the coal conversion rate during this experiment period was lower than that reported in Table 6 . The highest coal conversion rate of this operation period was $57 \%$, and the lowest was $20 \%$. Comparing part III-1 and part III-2 with part III-6 and part III-7, it can be found out that the carbon conversion rate did not decrease with the increase in coal input in the reductor. This means that more coal could be gasified in the reductor, which improved the gasification efficiency of coal.

Figure 5 presents the observed effect of variations in operational parameters on carbon content of fly ash and carbon conversion rate during the experiment duration periods. The changing pattern of stage I steam was strongly correlated with that of the carbon conversion rate. In addition, it was observed that the carbon conversion rate in stage II showed a direct relationship with the steam injection rate in stage I. A higher carbon conversion rate was achieved in stage II as the injection rate of steam in stage I was increased. 
Table 8. Long period test results.

\begin{tabular}{|c|c|c|c|c|c|c|c|c|c|c|c|c|c|c|c|c|}
\hline & & III-1 & III-2 & III-3 & III-4 & III-5 & III-6 & III-7 & III-8 & III-9 & III-10 & III-11 & III-12 & III-13 & III-14 & III-15 \\
\hline Stage I coal input & $\mathrm{kg} / \mathrm{h}$ & 71,611 & 71,802 & 71,906 & 71,651 & 69,442 & 69,729 & 66,226 & 65,661 & 63,235 & 63,602 & 63,802 & 64,899 & 66,443 & 61,552 & 66,398 \\
\hline Stage I steam injection & $\mathrm{kg} / \mathrm{h}$ & 4006 & 4388 & 4769 & 4387 & 4793 & 5586 & 5199 & 3596 & 4006 & 3920 & 3999 & 3983 & 3959 & 3950 & 3898 \\
\hline Stage II coal input & $\mathrm{kg} / \mathrm{h}$ & 7810 & 8198 & 7759 & 8078 & 9055 & 10,087 & 8111 & 7867 & 6020 & 7611 & 8024 & 7801 & 8010 & 8337 & 8226 \\
\hline Stage II steam injection & $\mathrm{kg} / \mathrm{h}$ & 4829 & 4867 & 4804 & 4988 & 4935 & 4667 & 4956 & 4375 & 4106 & 4262 & 4350 & 4510 & 4548 & 4596 & 4688 \\
\hline Total oxygen & $\mathrm{kg} / \mathrm{h}$ & 61,379 & 61,963 & 61,356 & 60,112 & 61,038 & 60,444 & 57,247 & 57,032 & 56,099 & 56,259 & 56,134 & 56,172 & 56,630 & 56,069 & 56,326 \\
\hline $\mathrm{H}_{2}$ content & $\%$ & 26.91 & 27.05 & 27.41 & 26.53 & 26.87 & 27.63 & 27.07 & 27.13 & 26.6 & 26.71 & 27.12 & 26.98 & 26.74 & 26.95 & 26.76 \\
\hline CO content & $\%$ & 58.38 & 57.52 & 57.67 & 56.85 & 57.92 & 57.48 & 56.58 & 57.56 & 56.35 & 56.43 & 56.83 & 56.74 & 56.82 & 57.01 & 56.53 \\
\hline $\mathrm{CO}_{2}$ content & $\%$ & 2.75 & 2.69 & 2.75 & 2.76 & 2.76 & 2.83 & 3.06 & 2.7 & 2.8 & 2.67 & 2.66 & 2.75 & 2.71 & 2.78 & 2.76 \\
\hline $\mathrm{CH}_{4}$ content & ppm & 11,906 & 10,646 & 10,147 & 12,433 & 10,574 & 11,800 & 12,064 & 9339 & 8551 & 10,106 & 12,305 & 10,934 & 10,157 & 10,026 & 10,172 \\
\hline Gas flow & $\mathrm{kNm}^{3} / \mathrm{h}$ & 182.0 & 187.1 & 186.5 & 189.6 & 185.7 & 190.2 & 175.7 & 182.0 & 170.0 & 176.2 & 179.6 & 171.9 & 172.2 & 170.1 & 172.1 \\
\hline $\begin{array}{c}\text { Carbon content of } \\
\text { A class ash }\end{array}$ & $\%$ & 32.04 & 31.33 & 37.54 & 28.97 & 30.11 & 33.52 & 29.77 & 27.82 & 35.18 & 43.78 & 42.67 & 38.4 & 40.07 & 44.9 & 41.46 \\
\hline $\begin{array}{c}\text { Carbon content of } \\
\text { B class ash }\end{array}$ & $\%$ & 36.57 & 32.7 & 38.88 & 31.2 & 29.7 & 31.78 & 32.46 & 31.46 & 35.6 & 39.4 & 43.1 & 40.66 & 42.45 & 45.9 & 42.5 \\
\hline Fly ash content & $\mathrm{kg} / \mathrm{h}$ & 5221 & 5279 & 5232 & 5255 & 5240 & 5381 & 4935 & 4871 & 4505 & 4718 & 4779 & 4818 & 4935 & 4682 & 4959 \\
\hline Carbon conversion rate & $\%$ & 40 & 47 & 27 & 51 & 57 & 54 & 52 & 55 & 28 & 21 & 22 & 30 & 25 & 18 & 24 \\
\hline
\end{tabular}




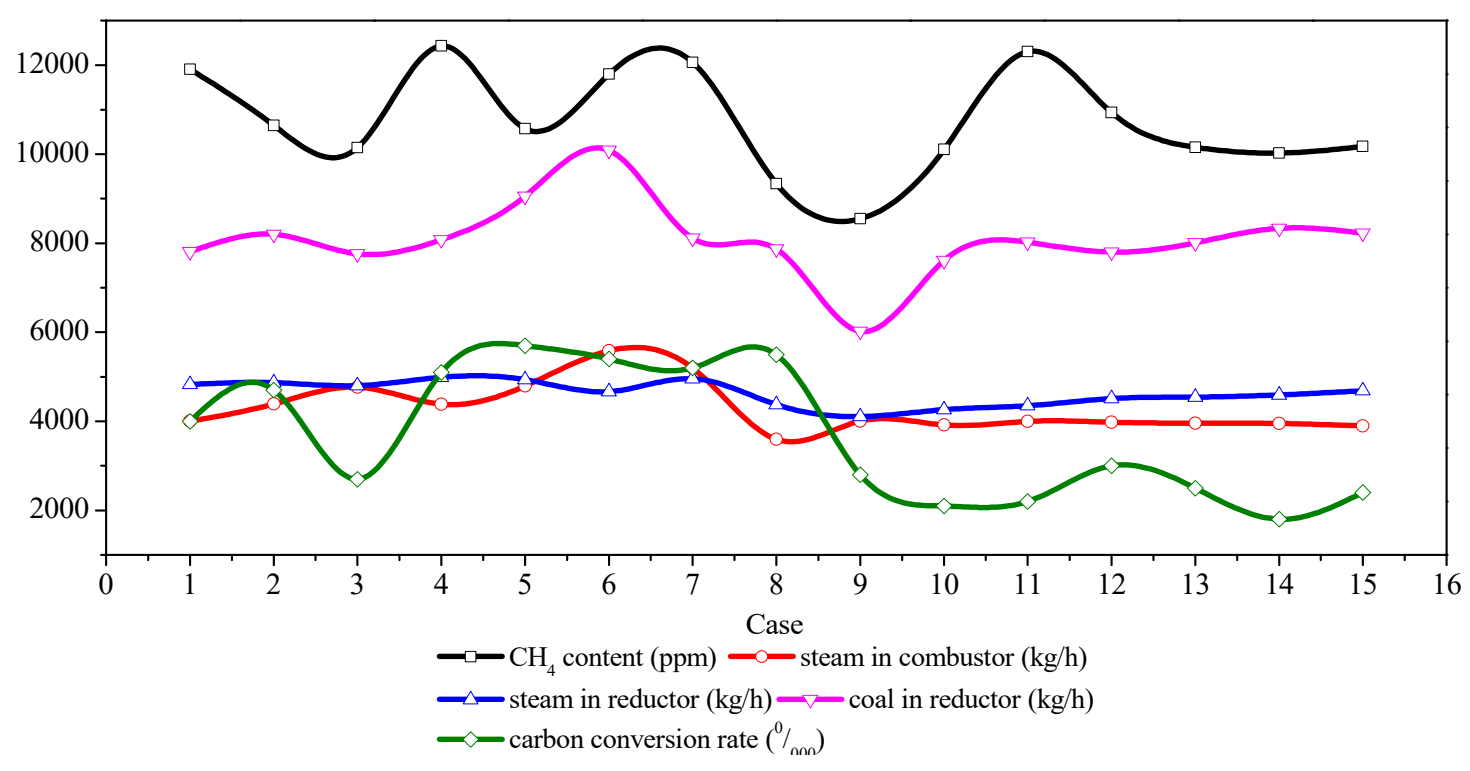

Figure 5. The effect of coal operation data to carbon conversion rate in reductor.

During the experiments, the output of $\mathrm{CH}_{4}$ and corresponding volume fraction were increased. The maximum volume fraction of $\mathrm{CH}_{4}$ reached $1.2 \%$, which was caused by the increase in coal input rate at stage II. The changes in $\mathrm{CH}_{4}$ output were consistent with the changes in the coal input rate. The average temperature in the gasification reaction region was reduced as a result of the high concentration of $\mathrm{CH}_{4}$ generated during pyrolysis and gasification reactions.

Figure 6 illustrates the yield of $\mathrm{CH}_{4}$ at different temperatures, simulated using the Aspen Plus gasification model. The Aspen Plus gasification model was applied to discuss the relationship between $\mathrm{CH}_{4}$ production and gasification temperature, which is always employed to analyze reaction state of pulverized coal [26]. The gasification processes I and II were simulated by Aspen Plus. The average temperature of the gasification process I is $1500^{\circ} \mathrm{C}$, and the average temperature of the gasification process II dropped to $1150^{\circ} \mathrm{C}$. It can be seen from Figure 6 that when $\mathrm{CH}_{4}$ yield is between $1 \%$ and $1.2 \%$, the gasification temperature is $1000-1050{ }^{\circ} \mathrm{C}$. However, according to measurement results, the syngas outlet temperature of the reductor is approximately $1150{ }^{\circ} \mathrm{C}$, which shows that the temperature of coal particles is not up to syngas temperature at the outlet of reductor.

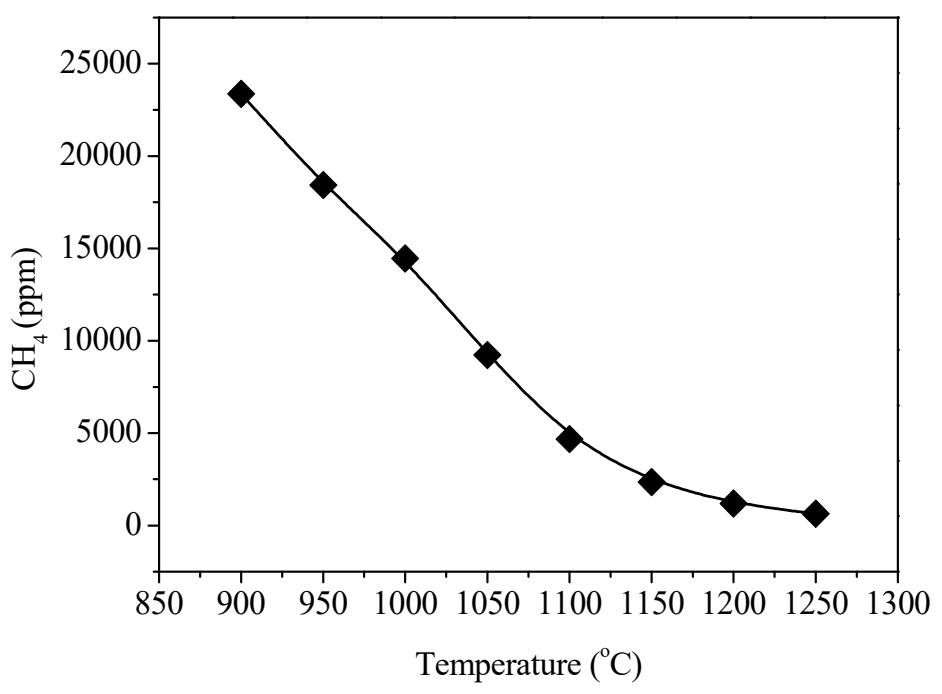

Figure 6. Simulation results of $\mathrm{CH}_{4}$ yield at different temperatures. 


\section{Conclusions}

The coal gasification characteristics in the reductor were experimentally studied in a full-scale two-stage pressure entrained-flow gasifier. The effects of the gasifying agent concentration and the coal input rate on coal gasification behaviors in the reductor were investigated. In addition, the performance of the gasifier operated for a long duration period under high load condition was further evaluated, and further experiments on coal gasification characteristics in the reductor were conducted. The effects of amount of coal fed into the reductor on syngas production $\left(\mathrm{CO}_{2}, \mathrm{H}_{2}, \mathrm{CO}\right.$, and $\left.\mathrm{CH}_{4}\right)$ were revealed as well. The main conclusions are as follows:

With an increase in the concentrations of gasifying agents, the gasifying agents can react with unconverted carbon to enhance the conversion rate. When the steam input in the combustor was increased from $3318 \mathrm{~kg} / \mathrm{h}$ to $5722 \mathrm{~kg} / \mathrm{h}$, the outputs of $\mathrm{H}_{2}, \mathrm{CO}$, and $\mathrm{CO}_{2}$ could be increased obviously, and the output of $\mathrm{CH}_{4}$ was lowered slightly. When the coal input was raised from $5481 \mathrm{~kg} / \mathrm{h}$ to $6689 \mathrm{~kg} / \mathrm{h}$, the outputs of $\mathrm{H}_{2}, \mathrm{CO}, \mathrm{CO}_{2}$, and $\mathrm{CH}_{4}$ were enlarged, and the volume fraction increment of $\mathrm{CH}_{4}$ was higher than those of other constituents. The carbon conversion rate was $70-80 \%$ when coal input was between $3000 \mathrm{~kg} / \mathrm{h}$ and $6000 \mathrm{~kg} / \mathrm{h}$. The carbon conversion rate in the reductor was greatly influenced by the steam injection at stage I. When the steam injection was inadequate, the carbon conversion rate declined considerably. When the coal input rate was raised from $8000 \mathrm{~kg} / \mathrm{h}$ to $10,000 \mathrm{~kg} / \mathrm{h}$ in the reductor, lower temperature in the gasification region caused the output of $\mathrm{CH}_{4}$ to increase, and the maximum volume fraction of $\mathrm{CH}_{4}$ could reach $1.24 \%$.

Author Contributions: Conceptualization: G.L. and C.W. (Chang'an Wang); investigation: G.L. and L.W.; resources: G.L. and C.W. (Chang'an Wang); data curation: P.W.; writing-original draft preparation: G.L. and C.W. (Chaowei Wang); writing-review and editing: C.W. (Chang'an Wang), C.W. (Chaowei Wang), and D.C.; funding acquisition: G.L. and C.W. (Chang'an Wang). All authors have read and agreed to the published version of the manuscript.

Funding: This research was funded by the China Postdoctoral Science Foundation (Grant No. 2019T120286) and the Foundation of State Key Laboratory of High-efficiency Utilization of Coal and Green Chemical Engineering (Grant No. 2020-KF-01).

Conflicts of Interest: The authors declare no conflict of interest.

\section{Nomenclature}

HNCERI Huaneng Clean Energy Research Institute

MHI Mitsubishi Heavy Industries

VM Volatile matter

SGC Syngas cooler

$\mathrm{O}_{2} /$ coal Oxygen-coal ratio $(\mathrm{kg} / \mathrm{kg})$

$\mathrm{H}_{2} \mathrm{O} /$ coal Steam-coal ratio $(\mathrm{kg} / \mathrm{kg})$

CCE Carbon conversion rate (\%)

$V_{\text {dry,gas }} \quad$ Volume flow rate of dry product gas $\left(\mathrm{Nm}^{3} / \mathrm{h}\right)$

$G_{R, \text { coal }} \quad$ Mass flow rate of coal into the reductor $(\mathrm{kg} / \mathrm{h})$

$G_{\text {ash }} \quad$ Mass flow rate of ash flow $(\mathrm{kg} / \mathrm{h})$

$m_{\mathrm{t}} \quad$ Total material increased $(\mathrm{kg} / \mathrm{h})$

$m_{\mathrm{c}} \quad$ Coal increased $(\mathrm{kg} / \mathrm{h})$

$m_{\mathrm{S}} \quad$ Steam increased $(\mathrm{kg} / \mathrm{h})$

$m_{\mathrm{g}} \quad$ Syngas increased $(\mathrm{kg} / \mathrm{h})$

$m_{\mathrm{H}_{2}} \quad \mathrm{H}_{2}$ increased $(\mathrm{kg} / \mathrm{h})$

$m_{\mathrm{CO}} \quad$ CO increased $(\mathrm{kg} / \mathrm{h})$

$m_{\mathrm{CO}_{2}} \quad \mathrm{CO}_{2}$ increased $(\mathrm{kg} / \mathrm{h})$

$m_{\mathrm{CH}_{4}} \quad \mathrm{CH}_{4}$ increased $(\mathrm{kg} / \mathrm{h})$ 


\section{References}

1. Wang, C.; Zhao, L.; Yuan, M.; Du, Y.; Zhu, C.; Liu, Y.; Che, D. Effects of minerals containing sodium, calcium, and iron on oxy-fuel combustion reactivity and kinetics of Zhundong coal via synthetic coal. J. Therm. Anal. Calorim. 2020, 139, 261-271. [CrossRef]

2. Wang, C.; Zhao, L.; Sun, R.; Hu, Y.; Tang, G.; Chen, W.; Du, Y.; Che, D. Effects of silicon-aluminum additives on ash mineralogy, morphology, and transformation of sodium, calcium, and iron during oxy-fuel combustion of zhundong high-alkali coal. Int. J. Greenh. Gas Control 2019, 91, 102832. [CrossRef]

3. Bielowicz, B. Petrographic Characteristics of Coal Gasification and Combustion by-Products from High Volatile Bituminous Coal. Energies 2020, 13, 4374. [CrossRef]

4. Wang, Q.; Dogot, T.; Yang, Y.; Jiao, J.; Shi, B.; Yin, C. From "Coal to Gas" to "Coal to Biomass": The Strategic Choice of Social Capital in China. Energies 2020, 13, 4171. [CrossRef]

5. Xu, G.; Murakami, T.; Suda, T.; Matsuzaw, Y.; Tani, H. Two-stage dual fluidized bed gasification: Its conception and application to biomass. Fuel Process. Technol. 2009, 90, 137-144. [CrossRef]

6. Geng, Y.; Che, D. An extended DEM-CFD model for char combustion in a bubbling fluidized bed combustor of inert sand. Chem. Eng. Sci. 2011, 66, 207-219. [CrossRef]

7. Singh, R.I.; Brink, A.; Hupa, M. CFD modeling to study fluidized bed combustion and gasification. Appl. Therm. Eng. 2013, 52, 585-614. [CrossRef]

8. Albal, R.S.; Litka, A.F.; Neoh, K.G.; Westra, L.F.; Woodroffe, J.A.; Stickler, D.B.; Gannon, R.E. Advanced 2-stage gasification system: 1. Experimental results. Ind. Eng. Chem. Res. 1989, 28, 1600-1607. [CrossRef]

9. Xu, S.; Ren, Y.; Wang, B.; Xu, Y.; Chen, L.; Wang, X.; Xiao, T.-C. Development of a novel 2-stage entrained flow coal dry powder gasifier. Appl. Energy 2014, 113, 318-323. [CrossRef]

10. Jeong, Y.-S.; Choi, Y.-K.; Park, K.-B.; Kim, J.-S. Air co-gasification of coal and dried sewage sludge in a two-stage gasifier: Effect of blending ratio on the producer gas composition and tar removal. Energy 2019, 185, 708-716. [CrossRef]

11. Zhang, J.; Wang, Z.; Zhao, R.; Wu, J. Gasification of Shenhua Bituminous Coal with $\mathrm{CO}_{2}$ : Effect of Coal Particle Size on Kinetic Behavior and Ash Fusibility. Energies 2020, 13, 3313. [CrossRef]

12. Chen, J.; Chen, W.; Jiao, Y.; Wang, X. Gasification Kinetics of Bituminous Coal Char in the Mixture of $\mathrm{CO}_{2}$, $\mathrm{H}_{2} \mathrm{O}, \mathrm{CO}$, and $\mathrm{H}_{2}$. Energies 2019, 12, 496. [CrossRef]

13. Ren, Y.; Xu, S.; Li, G. Experimental Study on the Operational Performance of an Advanced Two-Stage Entrained-Flow Coal Gasifier. Energy Fuels 2014, 28, 4911-4917. [CrossRef]

14. Chen, C.; Miyoshi, T.; Kamiya, H.; Horio, M.; Kojima, T. On the scaling-up of a two-stage air blown entrained flow coal gasifier. Can. J. Chem. Eng. 1999, 77, 745-750. [CrossRef]

15. Chen, C.; Horio, M.; Kojima, T. Numerical simulation of entrained flow coal gasifiers. Part I: Modeling of coal gasification in an entrained flow gasifier. Chem. Eng. Sci. 2000, 55, 3861-3874. [CrossRef]

16. Chen, C.; Horio, M.; Kojima, T. Numerical simulation of entrained flow coal gasifiers. Part II: Effects of operating conditions on gasifier performance. Chem. Eng. Sci. 2000, 55, 3875-3883. [CrossRef]

17. Chen, C.; Horio, M.; Kojima, T. Use of numerical modeling in the design and scale-up of entrained flow coal gasifiers. Fuel 2001, 80, 1513-1523. [CrossRef]

18. Watanabe, H.; Otaka, M. Numerical simulation of coal gasification in entrained flow coal gasifier. Fuel 2006, 85, 1935-1943. [CrossRef]

19. Shi, S.-P.; Zitney, S.E.; Shahnam, M.; Syamlal, M.; Rogers, W.A. Modelling coal gasification with CFD and discrete phase method. J. Energy Inst. 2006, 79, 217-221. [CrossRef]

20. Silaen, A.; Wang, T. Effect of turbulence and devolatilization models on coal gasification simulation in an entrained-flow gasifier. Int. J. Heat Mass Transf. 2010, 53, 2074-2091. [CrossRef]

21. Liu, Y.H.; Chen, W.; Che, D.F.; Cao, Z.D.; Guo, L.; Joseph, D.D.; Matsumoto, Y.; Sommerfeld, Y.; Wang, Y. Comparisons of four quench methods for high temperature Syngas-Exergy Analyses. AIP Conf. Proc. 2010, $1207,674$.

22. Yang, Z.; Liu, Y.; Cao, Z. Study of Chemical Quench of High Temperature Syngas. Int. J. Chem. React. Eng. 2011, 9, 2703-2723. [CrossRef]

23. Peralta, D.; Paterson, N.; Dugwell, D.; Kandiyoti, R. Pyrolysis and CO2Gasification of Chinese Coals in a High-Pressure Wire-Mesh Reactor under Conditions Relevant to Entrained-Flow Gasification. Energy Fuels 2005, 19, 532-537. [CrossRef] 
24. Wang, B.; Li, X.; Xu, S.; Paterson, N.; Dugwell, D.R.; Kandiyoti, R. Performance of Chinese Coals under Conditions Simulating Entrained-Flow Gasification. Energy Fuels 2005, 19, 2006-2013. [CrossRef]

25. Li, X.; Li, G.; Cao, Z.; Xu, S. Research on Flow Characteristics of Slag Film in a Slag Tapping Gasifier. Energy Fuels 2010, 24, 5109-5115. [CrossRef]

26. Gao, R.; Huang, B.; Huang, J.; Xu, J.; Dai, Z.; Wang, F. Process modelling of two-stage entrained-bed gasification composed of rapid pyrolysis and gasification processes. Fuel 2020, 262, 116531. [CrossRef]

27. Watanabe, H.; Ahn, S.; Tanno, K. Numerical investigation of effects of CO 2 recirculation in an oxy-fuel IGCC on gasification characteristics of a two-stage entrained flow coal gasifier. Energy 2017, 118, 181-189. [CrossRef]

28. Wang, L.; Jia, Y.; Kumar, S.; Li, R.; Mahar, R.B.; Ali, M.; Unar, I.N.; Sultan, U.; Memon, K. Numerical analysis on the influential factors of coal gasification performance in two-stage entrained flow gasifier. Appl. Therm. Eng. 2017, 112, 1601-1611. [CrossRef]

29. Alam, S.; Wijayanta, A.T.; Nakaso, K.; Fukai, J. Study on coal gasification with soot formation in two-stage entrained-flow gasifier. Int. J. Energy Environ. Eng. 2015, 6, 255-265. [CrossRef]

30. Jeong, Y.-S.; Choi, Y.-K.; Kang, B.-S.; Ryu, J.-H.; Kim, H.-S.; Kang, M.-S.; Ryu, L.-H.; Kim, J.-S. Lab-scale and pilot-scale two-stage gasification of biomass using active carbon for production of hydrogen-rich and low-tar producer gas. Fuel Process. Technol. 2020, 198, 106240. [CrossRef]

31. Jahromi, M.Y.; Atashkari, K.; Kalteh, M. Development of a high-temperature two-stage entrained flow gasifier model for the process of biomass gasification and syngas formation. Int. J. Energy Res. 2019, 43, 5864-5878. [CrossRef]

32. Niu, M.; Huang, Y.; Jin, B.; Liang, S.; Dong, Q.; Gu, H.; Sun, R. A novel two-stage enriched air biomass gasification for producing low-tar high heating value fuel gas: Pilot verification and performance analysis. Energy 2019, 173, 511-522. [CrossRef]

33. Pei, H.; Wang, X.; Dai, X.; Jin, B.; Huang, Y. A novel two-stage biomass gasification concept: Design and operation of a 1.5 MWth demonstration plant. Bioresour. Technol. 2018, 267, 102-109. [CrossRef] [PubMed]

(C) 2020 by the authors. Licensee MDPI, Basel, Switzerland. This article is an open access article distributed under the terms and conditions of the Creative Commons Attribution (CC BY) license (http://creativecommons.org/licenses/by/4.0/). 